
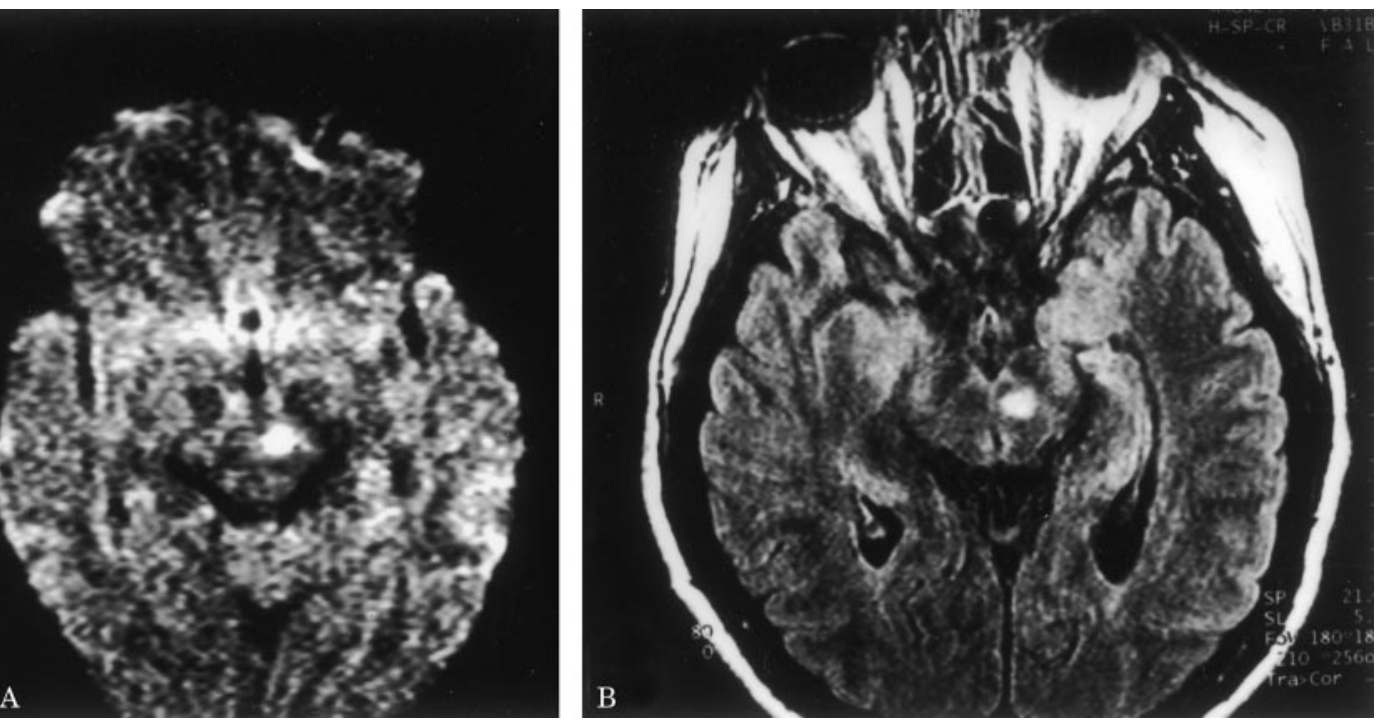

Figure. (A) Axial diffusion-weighted MRI demonstrates an acute to subacute lacunar infarct in the left midbrain. (B) Axial FLAIR (fluid-attenuated inversion recovery) MRI of the brain demonstrates hyperintensity predominantly involving the left red nucleus and the left substantia nigra. The infarct extended rostrally to just below the subthalamic nucleus and laterally to the margin of the cerebral peduncle.

\section{Midbrain infarct with parkinsonism}

John C. Morgan, MD, PhD; and Kapil D. Sethi, MD, FRCP

A 65-year-old dextral woman with hypertension presented with a 5-day history of difficulty writing. On examination, she had impaired adduction of her left eye and micrographia. MRI demonstrated an acute to subacute lacunar infarct involving predominantly the left red nucleus and the substantia nigra pars

From the Department of Neurology (Dr. Morgan), University of Virginia, Charlottesville; and Department of Neurology (Dr. Sethi), Medical College of Georgia, Augusta.

Received September 23, 2002. Accepted in final form January 16, 2003.

Address correspondence and reprint requests to Dr. J.C. Morgan, Department of Neurology, University of Virginia, Box 800394, Charlottesville, VA 22908; e-mail: jcm8e@virginia.edu compacta (figure). Three weeks later, her extraocular movements were normal; however, she had bradykinesia and micrographia in her right arm (without tremor). She was treated with carbidopa/ levodopa, and her bradykinesia and micrographia improved. Treatment with carbidopa/levodopa was discontinued after 2 months without worsening of her clinical condition.

Parkinsonism due to a focal ischemic lesion is very rare, and only about one-third of patients with all forms of vascular parkinsonism respond to levodopa treatment., The majority of patients with parkinsonism due to a focal ischemic lesion do not exhibit tremor, unlike patients with idiopathic PD. ${ }^{1,2}$

1. Winikates J, Jankovic J. Clinical correlates of vascular parkinsonism. Arch Neurol 1999,56:98-102.

2. Demirkiran M, Bozdemir H, Sarica Y. Vascular parkinsonism: a distinct, heterogeneous clinical entity. Acta Neurol Scand 2001;104:63-67. 


\section{Neurology}

\section{Midbrain infarct with parkinsonism}

John C. Morgan and Kapil D. Sethi

Neurology 2003;60;E10

DOI 10.1212/01.WNL.0000059550.37650.7C

This information is current as of June 24, 2003

\section{Updated Information \& Services}

References

Citations

Subspecialty Collections

Permissions \& Licensing

Reprints including high resolution figures, can be found at: http://n.neurology.org/content/60/12/E10.full

This article cites 2 articles, 0 of which you can access for free at: http://n.neurology.org/content/60/12/E10.full\#ref-list-1

This article has been cited by 1 HighWire-hosted articles: http://n.neurology.org/content/60/12/E10.full\#\#otherarticles

This article, along with others on similar topics, appears in the following collection(s):

\section{All Cerebrovascular disease/Stroke}

http://n.neurology.org/cgi/collection/all_cerebrovascular_disease_strok e

All Imaging

http://n.neurology.org/cgi/collection/all_imaging

Infarction

http://n.neurology.org/cgi/collection/infarction

MRI

http://n.neurology.org/cgi/collection/mri

Parkinson's disease/Parkinsonism

http://n.neurology.org/cgi/collection/parkinsons_disease_parkinsonism

Information about reproducing this article in parts (figures,tables) or in its entirety can be found online at:

http://www.neurology.org/about/about_the_journal\#permissions

Information about ordering reprints can be found online:

http://n.neurology.org/subscribers/advertise

Neurology ${ }^{\circledR}$ is the official journal of the American Academy of Neurology. Published continuously since 1951, it is now a weekly with 48 issues per year. Copyright . All rights reserved. Print ISSN: 0028-3878. Online ISSN: 1526-632X.

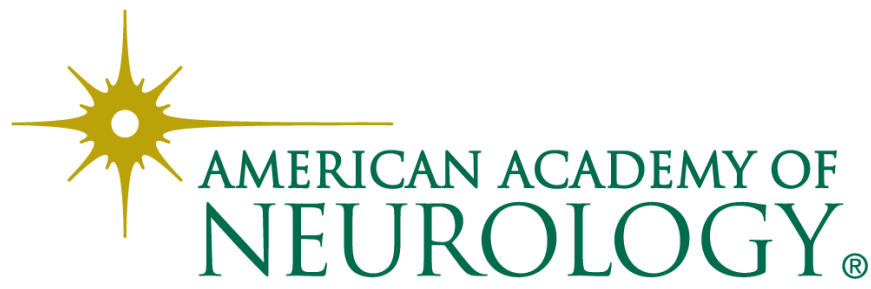

